ISSUES IN MEDICINE

\title{
Recommendations for the medical evaluation of children prior to adoption in South Africa
}

\author{
A F Haeri Mazanderani, N M du Plessis, J Lumb, U D Feucht, M Myburgh, S H Mayaphi, M R Lekalakala, D W Swanepoel, \\ H Georgakis, T Avenant
}

Ahmad Haeri Mazanderani is a registrar in the Department of Medical Virology, Tshwane Academic Division, National Health Laboratory Service, and University of Pretoria, South Africa. Nicolette du Plessis is a paediatric infectious diseases specialist in the Department of Paediatrics and Child Health, University of Pretoria and Kalafong Hospital, Pretoria. Janet Lumb is a paediatrician working for the Thusanani Children's Foundation, Gauteng, South Africa. Ute Feucht is principal paediatrician on the Tshwane District Clinical Specialist Team and a senior lecturer in the Department of Paediatrics, Kalafong Hospital and University of Pretoria. Marcelle Myburgh is a clinical virologist in the Department of Medical Virology, Tshwane Academic Division, National Health Laboratory Service, and University of Pretoria. Simnikiwe Mayaphi is a clinical virologist in the Department of Medical Virology, Tshwane Academic Division, National Health Laboratory Service, and University of Pretoria. Ruth Lekalakala is principal pathologist and a senior lecturer in the Department of Medical Microbiology, Tshwane Academic Division, National Health Laboratory Service, and University of Pretoria. De Wet Swanepoel is an associate professor in the Department of Communication Pathology, Faculty of Humanities, University of Pretoria. Hellen Georgakis is a medical officer in the Department of Neurosurgery, Chris Hani Baragwanath Academic Hospital, Johannesburg, South Africa. Theuns Avenant is a chief specialist in and head of the Department of Paediatrics at Kalafong Hospital and University of Pretoria.

Corresponding author: A Haeri Mazanderani (ahmad.haerimazanderani@up.ac.za)

The current legislative framework in South Africa (SA) supports adoption as the preferred form of care for children with inadequate or no parental or family support. There are an estimated 3.8 million orphans in SA, with approximately 1.5 - 2 million children considered adoptable. As a means of improving services, newly drafted adoption guidelines from the National Department of Social Development will in future require both non-profit and private sector adoption agencies to obtain a medical report on a child prior to placement. However, no local guidelines specify what an appropriate medical examination entails or how it should be reported. For the purposes of proposing and developing such guidelines, an open forum was convened at the Institute of Pathology, University of Pretoria, in March 2013. These 'Recommendations for the medical evaluation of children prior to adoption in South Africa' emanate from this meeting.

S Afr Med J 2014;104(8):544-549. DOI:10.7196/SAMJ.7958

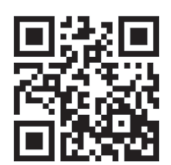

There are an estimated 3.8 million orphans in South Africa (SA). ${ }^{[1]}$ This includes children without a living biological mother, father or both parents. It is further estimated that half of these children have been orphaned on account of AIDS. ${ }^{[2]}$ The number of orphans has risen dramatically over the past 10 years, with double orphans, children who have neither a father nor a mother, increasing from 350000 to $885000 .^{[1]}$ The current legislative framework in SA supports adoption as the preferred form of care for children with inadequate or no parental or family support, ${ }^{[3]}$ and approximately 1.5 - 2 million children are considered adoptable. ${ }^{[4]}$ As a means of improving services, newly drafted adoption guidelines from the National Department of Social Development will in future require both non-profit and private sector adoption agencies to obtain a medical report on a child prior to placement. ${ }^{[5]}$ However, in contrast to international adoption practice, no local guidelines exist that specify what an appropriate medical examination entails or how it should be reported. For the purposes of proposing and developing such guidelines, an open forum was convened at the University of Pretoria's Institute of Pathology in March 2013. The forum was attended by a number of stakeholders, including the South African National Adoption Coalition, and the diverse range of participants included social workers, healthcare professionals and representatives of child protection organisations (CPOs) and civil society groups, as well as adoptive parents. Representatives of the National Department of Health, the National Department of Social Development and the South African National AIDS Council were notified and invited to the forum, but did not attend. We anticipate that the recommendations proposed will both raise awareness of the need to implement a national minimum standard for the medical evaluation of children prior to adoption and provide a framework for the details thereof.

\section{Defining guidelines}

A cost-effective national minimum standard, completed by a registered medical practitioner and available for all national adoptions in SA, needs to be introduced. Such a measure should be implemented for all placements categorised as unrelated and related adoptions, with the exception of step-adoption. The need to evaluate children prior to step-adoption, the most popular form of adoption in SA, ${ }^{[3]}$ should be assessed on an individual basis. In addition, all abandoned children should undergo the same comprehensive evaluation, as adoption will be the most appropriate form of care for most of them. The following recommendations are in keeping with section 28 of the Constitution of the Republic of South Africa, ${ }^{[6,7]}$ which specifies that all children have the right to basic healthcare services and that the child's best interests are of paramount importance. Furthermore, as the recommendations comprise an essential component of primary healthcare they fall within the ambit of the National Health Act, ${ }^{[8]}$ which ensures that such services are provided free of charge to children under the age of 6 years. 


\section{Inherent challenges}

The medical evaluation of children prior to adoption is inherently challenging. Early placement is preferable, but it has to be accompanied by a high standard of medical care if it is to be successful. $^{[9]}$ Placement of children with undiagnosed medical conditions can have negative consequences, both for the children and for the families that adopt them. It is therefore advisable to perform a comprehensive medical evaluation prior to placement, both to ensure appropriate intervention and treatment of the child and to inform prospective adopters regarding likely future medical needs and care. This may prove extremely challenging when resources and expertise are limited, as is the case in SA, where the feasibility of such an undertaking needs to be carefully considered. No matter how extensive the medical evaluation of a child, future problems or pathology can never be completely excluded. Other considerations are the risks of escalating costs, delaying or preventing the placement of a perfectly healthy child on medical or developmental grounds, and creating unnecessary anxiety in the prospective parent(s).

Another challenge is to develop guidelines that are appropriate for a diverse group of children of different ages and with different risk profiles. This problem is further compounded by a lack of data to inform local practice. Implementing national guidelines in the context of fragmented social services may also prove challenging. Adoption services require the participation of numerous stakeholders, including the Department of Social Development, the Department of Home Affairs, the children's courts, the social workers operating under a registered $\mathrm{CPO}$, and the numerous individuals and organisations that care for children prior to adoption. The role of the Department of Health regarding adoption services has not been clearly delineated. The Children's Act ${ }^{[10]}$ states that in certain circumstances the state may be required to pay for a child's HIV test for the purpose of placing the child in foster care or adoption. Importantly, it also states that consent for HIV testing in children under 12 years of age may be obtained from a designated CPO arranging the placement of the child, as well as from the superintendent or person in charge of a hospital. ${ }^{[11]}$ However, apart from HIV testing, nothing is specifically mentioned regarding the medical evaluation of children being placed for adoption. Indeed, non-profit organisations wishing to obtain medical evaluations for children in their care have reported being turned away from public healthcare facilities on the grounds that such facilities do not provide medical screening services for apparently healthy children being placed for adoption.

\section{Feasibility of implementing guidelines}

In SA, approximately 2000 court-ordered adoptions are processed per year, and the figure is thought to be decreasing. ${ }^{[3]}$ This stands in stark contrast to the number of children being placed in foster care, which has more than doubled since 2004, gauged by the 572903 Foster Care Grants issued in 2012. ${ }^{[12]}$ The imperative to adequately address the health needs of this vulnerable group, and the additional 1.6 million orphans thought to be living 'informally' with extended family members, ${ }^{[13]}$ is reflected by unacceptably high under-5 mortality rates and the inevitable failure of SA to meet Millennium Development Goal 4, aiming at a reduction in child mortality ${ }^{[14]}$ Although a comprehensive medical assessment at each foster care placement would be ideal, it may prove unrealistic in the context of existing public health services. The nature of adoption as a permanent relationship differentiates it from temporary forms of care, in which social workers can follow children up on an ongoing basis. Adoption therefore represents a cost-effective opportunity for comprehensive medical assessment and intervention.
There are no official statistics regarding abandoned children, although it is estimated that more than 2000 babies are abandoned each year. ${ }^{[15]}$ Most of these children will be adoptable, and many of them are neonates when found. This provides an opportunity for clinical and laboratory screening tests as well as medical interventions. These infants should undergo the same medical evaluation as older children prior to adoption.

\section{The medical report on children prior to adoption}

In an attempt to ensure that a quality medical evaluation is performed on all abandoned children and children prior to adoption, it is recommended that a standard medical form be developed and adopted at a national level (Appendix 1; available in the online version of this article). The following details need to be documented in such assessments:

\section{Identifying details}

Identifying details that need to appear on the medical report should include the name of the child, date of birth or estimated age, and gender. Since children may present for healthcare evaluation before being issued with a birth certificate, as in the case of abandoned children, it is imperative that such children be provided with a name, surname and date of birth. These details should be used consistently and reflected on all laboratory results, the Road to Health booklet (RTHB) or equivalent immunisation record, and the birth certificate once it is issued. This practice should also be maintained in circumstances where the child is unlikely to be cared for by his/her biological parent(s) and when there is uncertainty regarding the name (e.g. the use of maternal or paternal surname). For determination of the age of children other than neonates who have no prior documentation, there are a number of bone and dental age assessment methods that have been described in the medical literature. ${ }^{[16]}$ The Greulich and Pyle method is still commonly used in SA and can be arranged at radiology departments with the relevant expertise in the public health sector. It is important to note that such assessments are estimates at best and cannot accurately determine age. ${ }^{[16]}$

\section{Medical history}

Obtaining a comprehensive history from the biological mother or caregiver at first contact with a healthcare worker is essential, as this may be the only opportunity to do so. Ideally, the RTHB should be completed and a copy of it attached to the medical report. It is recommended that the details listed in Table 1 be explicitly recorded on the medical report, as RTHBs are sometimes inadequately completed.

\section{Medical examination}

The medical examination should include details of a full systemic examination with syndromic screening and anthropometric parameters (Table 2).

\section{Special investigations}

In addition to a cranial ultrasound scan and opthalmological assessment in selected high-risk cases, all children will require laboratory screening tests (Table 3 ).

\section{Infectious disease screening}

An overwhelming number of infectious agents, including viruses, bacteria, parasites and fungi, can be transmitted from mother to child. Some of these pathogens are associated with severe congenital 


\begin{tabular}{|c|}
\hline Birth history \\
\hline Place of birth \\
\hline Mode of delivery \\
\hline Gestational age \\
\hline Apgar score \\
\hline Birth parameters: weight, length, head circumference \\
\hline Neonatal complications \\
\hline Maternal history \\
\hline Gravidity, parity and previous miscarriage/s or TOP \\
\hline Number of live children and their ages \\
\hline Death/s and cause/s of death of siblings \\
\hline Antenatal complications \\
\hline HIV rapid and ELISA results \\
\hline If HIV-infected: \\
\hline $\mathrm{CD}^{+}$cell count \\
\hline HIV viral load \\
\hline WHO staging \\
\hline PMTCT interventions \\
\hline $\mathrm{TB}$ and $\mathrm{TB}$ treatment \\
\hline STI, including RPR results \\
\hline History of smoking, alcohol and illicit drug use \\
\hline History of familial condition/s (including paternal family) \\
\hline Duration of breastfeeding and date at cessation \\
\hline General medical history \\
\hline RTHB availability \\
\hline Growth and immunisation history \\
\hline Developmental milestones \\
\hline Chronic diseases and medication \\
\hline $\begin{array}{l}\text { Previous hospital admissions, with dates, diagnoses and follow- } \\
\text { up plans }\end{array}$ \\
\hline $\begin{array}{l}\text { TOP = termination } / \text { s of pregnancy; ELISA = enzyme-linked immunosorbent assay; } \\
\text { WHO = World Health Organization; PMTCT }=\text { prevention of mother-to-child } \\
\text { transmission; TB = tuberculosis; } \mathrm{STI}=\text { sexually transmitted infection } / \mathrm{s} ; \mathrm{RPR}=\text { rapid } \\
\text { plasma reagin; RTHB = Road to Health booklet. }\end{array}$ \\
\hline
\end{tabular}

abnormalities and sequelae that may not be clinically apparent during the newborn period. Infectious diseases may also be acquired after delivery but before adoption. The American Academy of Pediatrics recommends the following infectious disease tests for screening international adoptees: hepatitis B, syphilis and HIV-1/2 serology; tuberculin skin testing or interferon-gamma release assay testing; stool examination for ova and parasites, including Giardia intestinalis; and Cryptosporidium antigen testing. ${ }^{[17]}$ A complete blood count and differential count is also recommended. In addition, the Centers for Disease Control and Prevention lists the following screening tests that may be useful, depending on the child's country of origin or specific risk factors: hepatitis A, hepatitis C and Trypanosoma cruzi serology; malaria smears; and Helicobacter pylori antigen screening of stool. ${ }^{[18]}$ Taking into account local prevalence, costs and the poor positive predictive value of some of the laboratory tests, we recommend limiting routine screening to exclusion of $\mathrm{HIV}-1 / 2$, hepatitis B and syphilis (Table 3). Other infectious disease markers

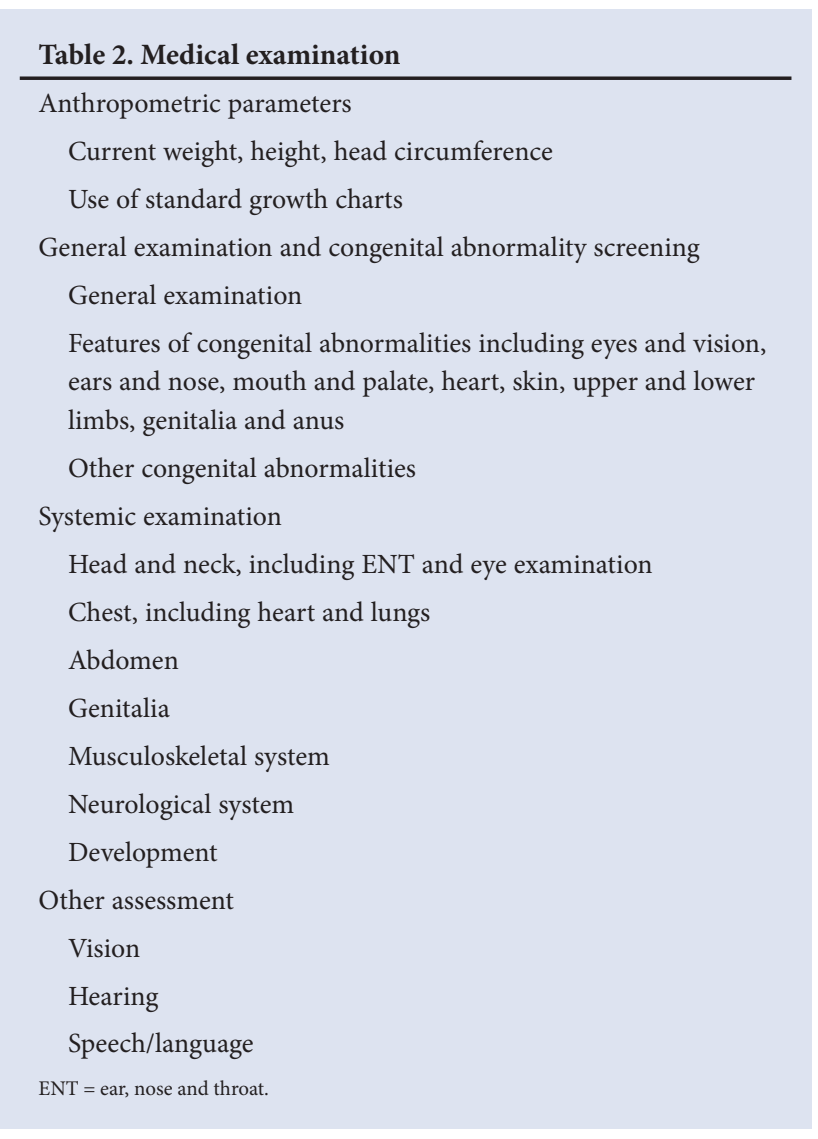

Table 3. Special investigations

\begin{tabular}{l}
\hline Laboratory screening tests \\
HIV-1/2 ELISA \\
HBsAg ELISA \\
Syphilis (treponemal or non-treponemal tests) \\
TSH (children $<28$ days) \\
Cranial ultrasound scan in children with a birth weight $<2000 \mathrm{~g}$ \\
if $<12$ months of age at time of assessment \\
Ophthalmological assessment in children with a birth weight \\
$<1500$ g regardless of age at time of assessment \\
ELISA = enzyme-linked immunosorbent assay; HBsAg = hepatitis B surface antigen; \\
TSH = thyroid-stimulating hormone.
\end{tabular}

and haematological testing should only be performed if the medical history suggests a high risk of infection or if clinically indicated. Investigation for tuberculosis (TB) is only recommended once TB exposure has been established. Because of the high prevalence of intestinal parasites in SA, routine deworming in children $>3$ years of age, rather than repeated stool sample collection, is considered cost-effective.

All children should have an HIV-1/2 enzyme-linked immunoassay (ELISA) test. An HIV-1/2 ELISA is preferable to a rapid test for reasons of quality control, including standardised reporting, and better sensitivity and specificity. Fourth-generation HIV-1/2 ELISA testing, which has the ability to detect antibodies to HIV-1/2 and p24 antigen simultaneously, reduces the window period to an average of 2 weeks, whereas rapid strips, which can only effectively detect HIV antibodies, have an average window period of $3-4$ weeks. ${ }^{[19]}$ 
A laboratory diagnosis of HIV-1/2 in a child $>18$ months of age requires a positive result on two assays and must be confirmed on a second specimen. In children $<18$ months of age, a positive HIV1/2 ELISA result suggests HIV exposure but not necessarily HIV infection, as maternal antibodies are transferred from the mother to the child. These children should be tested further in accordance with the current South African Antiretroviral Treatment Guidelines testing algorithm for infants $<18$ months of age, which includes immediate HIV-1 polymerase chain reaction (PCR) testing for 'symptomatic infants.' ${ }^{\text {[20] }}$ Additionally, immediate HIV-1 PCR testing can be considered for infants of mothers with known poor or non-compliance with prevention of mother-to-child transmission (PMTCT) interventions. However, infants with negative HIV-1 PCR results should have repeat testing as per guidelines.

A negative HIV-1/2 ELISA result adequately excludes HIV infection at the time of testing if no recent exposure has occurred. However, if a child was breastfed the test should be repeated 6 weeks after cessation of breastmilk feeds. As for all laboratory investigations, the limitations of the HIV assays need to be taken into consideration. Both qualitative and quantitative molecular HIV assays (i.e. PCR and viral load assays) currently used in the public health sector are not designed to test for HIV-2. Furthermore, in the context of PMTCT practices, repeat HIV PCR testing 4 - 6 weeks after cessation of prophylaxis may be prudent in view of increasing evidence suggesting that molecular HIV testing may not detect low-level viraemia as a result of antiretroviral therapy. ${ }^{[21,22]}$ Since it is not possible to exclude HIV infection completely in early infancy, prospective adoptive parents need to be counselled in this regard.

Screening for hepatitis B is recommended in all children by testing for hepatitis B surface antigen (HBsAg). Since false-negative results can be associated with early infection during the window period, it is advisable to repeat the test in 6 months if it is negative ${ }^{[18]}$ Falsepositive results can also occur and have been associated with HBsAg testing within 3 weeks of administering hepatitis B vaccination. ${ }^{[23]}$ In children with unknown immunisation records, hepatitis B surface antibody (HBsAb) testing can be used to confirm immunity.

Either non-treponemal (e.g. rapid plasma reagin (RPR), Venereal Disease Research Laboratory (VDRL)) or treponemal (e.g. Treponema pallidum haemagglutination assay (TPHA), fluorescent treponemal antibody-absorption (FTA-ABS), syphilis ELISA) testing can be used for syphilis screening purposes. Should the screening test be positive, a confirmatory test using an alternative assay type needs to be performed. The diagnosis of congenital syphilis can be difficult and results of maternal testing, if available, may prove valuable in this regard.

Herpesviruses have not been included as part of routine laboratory screening because of the poor positive predictive value of both serological and molecular assays. This includes screening for cytomegalovirus (CMV), a leading cause of developmental disabilities. The prognosis of congenital CMV is highly variable. The majority of patients are asymptomatic at birth (87.3\%), and only $13.5 \%$ of children develop hearing loss or impaired intellectual performance. However, hearing loss can occur as late as schoolgoing age in a child born with normal hearing. ${ }^{[24]}$ Similarly, the manifestations of congenital rubella can be delayed in up to $20 \%$ of cases, ${ }^{[25]}$ so routine laboratory testing is also not recommended. Testing should rather be based on assessment of individual risk.

Routine hepatitis $\mathrm{C}$ testing is not considered necessary in SA because of the low prevalence of hepatitis $\mathrm{C}$, estimated to be $<2 \%,{ }^{[26}$ and a low risk of mother-to-child transmission $(\sim 10 \%) \cdot{ }^{[27]}$ Although vertical transmission is reported to be considerably increased in the
HIV-positive population, ${ }^{[28]} \mathrm{HCV} / \mathrm{HIV}$ co-infection is uncommon in SA. ${ }^{[26]}$ Testing is therefore recommended only in high-risk cases, such as babies born to intravenous drug users.

Additional blood-borne pathogens that are readily transmitted from mother to child but are usually subclinical during childhood include human T-cell lymphotropic virus types 1 and 2 (HTLV-1 and 2). Although regions of SA are known to be endemic for HTLV-1, ${ }^{[29]}$ the lifetime risk of HTLV-1-associated disease is considered to be only $10 \%{ }^{[30]}$ Until data on the local incidence of mother-to-child transmission become available, informed recommendations are not possible.

\section{Thyroid function and metabolic screening}

Apart from screening for infectious diseases, blood tests should be performed for congenital hypothyroidism in neonates (i.e. in children who have been identified for adoption at birth, including abandoned neonates). Various algorithms are used globally, each with their own advantages and disadvantages, as outlined by the American Academy of Pediatrics. ${ }^{[31]}$ For children with a birth weight of $>2500$ g, thyroid-stimulating hormone (TSH) has proved to be an effective screening test. Since delayed TSH elevation is particularly common in infants of low birth weight (i.e. $<2500 \mathrm{~g}$ ), testing with a combination of TSH and thyroxine (T4) has better sensitivity in detecting hypothyroidism in such infants, in particular those with thyroid-binding globulin deficiency, central hypothyroidism and hypothyroxinaemia. Screening is recommended 2 - 4 days after birth for term babies and at $2-7$ days for preterm babies and those in neonatal intensive care units. If the above tests are abnormal, thyroid function tests should be done 2 weeks after delivery and treatment initiated if results suggest congenital hypothyroidism. Although considered rare, routine screening for congenital hypothyroidism is deemed appropriate as the condition is usually asymptomatic and can have devastating neurodevelopmental sequelae if left untreated.

Screening for metabolic disorders can also be considered in newborns prior to adoption, including testing for galactosaemia and phenylketonuria. However, we regard these tests as currently beyond the scope of a feasible national minimum standard appropriate for SA. Where resources allow, they can be incorporated as part of routine neonatal screening programmes.

\section{Allied health professional assessments}

It is recommended that all children have appropriate speech, language, audiometric, psychological and occupational therapy assessments. A number of developmental screening tools have been developed, and where available these may prove valuable. In particular, the Griffiths Mental Developmental Scales and Bayley Scales of Infant Development, when performed by a suitably trained person, can provide a cost-effective general indicator of subsequent development. ${ }^{[32]}$ However, extensive evaluation and treatment is considered beyond the scope of an appropriate national minimum standard. The assessments listed in Table 4 are considered an essential minimum for both identifying and addressing gross developmental disorders in high-risk children prior to adoption in SA. It is recommended that parents take their children for additional assessments in the postadoption period.

\section{Summary of medical evaluation}

A summary of the medical evaluation should be made with suggested medical follow-up and intervention if necessary, as well as any findings that may impact on the adoption of the child. As the medical evaluation of a child cannot completely exclude the possibility of 
Table 4. Allied health professional assessments

Audiological assessment An audiological screening test should be performed in children with risk factors for hearing loss, as described in the literature, ${ }^{[33]}$ including the following:

Any caregiver concerns or clinical concerns regarding hearing abnormalities

Family history of hearing loss

All children with a history of NICU admission or other neonatal risk factors associated with hearing loss, including in utero infections

Postnatal meningitis/encephalitis

Craniofacial anomalies and syndromes associated with hearing loss; neurodegenerative disorders

Head trauma

Medication such as chemotherapy, ototoxic antibiotics, etc.

Delayed speech and language development

The following audiological assessments are recommended for these children:

Children $<5$ years of age should be screened for hearing loss with electrophysiological devices measuring OAE or $\mathrm{ABR}$

Children who spent $\geq 5$ days in an NICU must be screened with ABR to identify possible cases of auditory neuropathy

Children $\geq 5$ years of age should be screened with behavioural pure-tone audiometry at $20 \mathrm{~dB}$ across 1000 , 2000 and $4000 \mathrm{~Hz}$

An abnormal screening test requires a diagnostic audiological assessment to determine whether hearing loss is present. Although children who fail the hearing screening test are at a significantly increased risk, the majority of these children will not have permanent hearing loss ${ }^{[34,35]}$

Occupational therapy An occupational therapy assessment is recommended in the following cases:

assessment

Children with a birth weight $<2000 \mathrm{~g}$ (assessed at or after 4 months corrected age)

All children $>3$ years of age

If there are any clinical concerns regarding developmental delay

Speech/language therapy

A speech/language therapy assessment is recommended in the following cases:

assessment

When there are clinical concerns regarding speech and language delays or abnormalities (e.g. cleft palate)

In infants with feeding difficulties

Psychological assessment A psychological assessment should be performed:

In all children with a history of abuse

If recommended by the social worker or examining clinician

Such an assessment may be performed by a clinical psychologist, educational psychologist or clinical social

worker

$\mathrm{OAE}=$ otoacoustic emissions; $\mathrm{ABR}=$ auditory brainstem response; $\mathrm{NICU}=$ neonatal intensive care unit.

future pathology, it is recommended that the medical report be considered valid for 3 months from the date of examination if the child is $<6$ months of age, and for 6 months from date of examination if the child is $\geq 6$ months of age.

\section{Conclusion}

An appropriate medical evaluation of children prior to adoption is an essential step towards achieving successful permanent placement of children with inadequate or no parental or family support, and as such represents a cost-effective opportunity to improve the health and well-being of a marginalised group in the SA population. It is hoped that by implementing the proposals outlined above, an effective model will be established for streamlining health services for orphaned and vulnerable children in general. This will ensure that key developmental goals, such as reducing child mortality and combating HIV/AIDS, are better addressed.
Participants in the forum. Janet Lumb, Nicolette du Plessis, Theunis Avenant, Michelle Meiring, Marcelle Myburgh, Karin Richter, Sue Krawitz, Pam Wilson, Marlene Visser, Nina de Caires, Phyllis Pau, Maretha Bekker, Caroline Rose, Harriet Leisegang, Ruth Lekalakala, Sim Mayaphi, Ute Feucht, Theresa Rossouw, Tahiyya Hassim, Karen Bruyere, Marieke Brauer, Rendani Mafuyeka, Dan Morobadi, Shivani Goolab, Mohamed Said, Tumi Tseledi, Charmaine van Eeden, Charles Persence, Kay McCrindle, Sumayya Carrim, De Wet Swanepoel, Crystal Theron, Ahmad Haeri Mazanderani.

Acknowledgements. The authors thank all the participants, including representatives of the South African National Adoption Coalition, Thusanani Children's Foundation, New BeginningZ, Tshwane Haven, Child Welfare Tshwane, Johannesburg Child Welfare, Boksburg Child 
Welfare, Impilo, Bright Start Right Start, Good Start Foundation, the Department of Neurosurgery at Chris Hani Baragwanath Academic Hospital and the University of the Witwatersrand, Red Cross War Memorial Children's Hospital and the University of Cape Town, the departments of Occupational Therapy, Communication Pathology, Ophthalmology, Family Medicine and Paediatrics at the University of Pretoria, and the departments of Chemical Pathology, Medical Microbiology and Medical Virology of the Tshwane Academic Division of the National Health Laboratory Service. We also thank Profs Lorna Jacklin and Haroon Saloojee for reviewing the manuscript.

1. Meintjes H, Hall K. Demography of South Africa’s children. In: Hall K, Woolard I, Lake L, et al., eds. South African Child Gauge 2012. Cape Town: Children's Institute, University of Cape Town, 2012:82-85. http://wwwci.org za/index php?option=com_content\&wiew=article\&id=997\&Itemid=399 (accessed 12 June 2013).

2. United Nations Children’s Fund. South Africa Annual Report 2011. Pretoria: United Nations Children Fund South Africa, 2011. http://www uniceforg/southafrica/SAF resources annualreport2011 pd (accessed 13 May 2013)

3. Mokomane Z, Rochat TJ, The Directorate. Adoption in South Africa: Trends and patterns in social work practice. Child \& Family Social Work 2012:17(3):347-358. [http://dx.doi.org/10.1111/j.13652206.2011.00789.x

4. Mokomane Z, Rochat T. The Perceptions, Understanding and Beliefs of People Towards Adoption and Blockages Which Prevent Communities From Adopting Children in South Africa. Pretoria: Human Sciences Research Council, 2010:vii-x.

5. South African National Department of Social Development. Guide to Good Practice on National Adoption. Pretoria: Department of Social Development (in press).

6. Section 28(1)(c) of the Constitution of the Republic of South Africa, 1996

7. Section 28(2) of the Constitution of the Republic of South Africa, 1996.

8. Section 4(3)(a) of the National Health Act No. 61 of 2003

9. Gordon RR. Medical Examination of the baby to be adopted. BMJ 1975;2(5961):31-32. [http://dx.doi. org/10.1136/bmj.2.5961.31]

10. Section 131 of the Children's Act No. 38 of 2005.

11. Section 130(2) of the Children's Act No. 38 of 2005

12. Hall K. Income poverty, unemployment and social grants. In: Hall K, Woolard I, Lake L et al., eds. South African Child Gauge 2012. Cape Town: Children's Institute, University of Cape Town, 2012:86-90. http://www.ci.org.za/index.php?option=com_content\&view=article\&id=997\&Itemid=39 (accessed 12 June 2013)

13. Jamieson K. Woolard I, Lake L et al, eds. South African Child Gauge 2012. Cape Town: Children's Institute, K, Woolard I, Lake L et al., eds. South African Child Gauge 2012. Cape Town: Childrens Institute, University of Cape Town, 2012:14-19. http://www ci.

14. Bhutta ZA, Chopra M, Axelson H, et al. Countdown to 2015 decade report (2000-10): Taking stock Bhutta ZA, Chopra M, Axelson H, et al. Countdown to 2015 decade report (2000-10): Taking stock of
maternal, newborn, and child survival. Lancet 2010;375(9730):2032-2044. [http://dx.doi.org/10.1016/ maternal, newborn, and child survival. Lancet 2010;375(9730):2032-2044. [http://dx.doi.org/10.101

15. Molatlhwa O. Over 2,000 kids thrown away yearly. Sowetan 2010; 1 July. http://www.sowetanlive.co.za/ ver-2000-kids-thrown-away-yearly (accessed 9 April 2013)

sessment Practices: A Literature Review \& Annotated Bibliography. New York: United Nations Children's Fund, 2011:13-27. http://www.unicef.org/protection/Age Assessment_Practices_2010.pdf (accessed 18 October 2013).
17. American Academy of Pediatrics. Medical evaluation of internationally adopted children for infectiou diseases. In: Red Book. 29th ed. Elk Grove Village, IL: American Academy of Pediatrics, 2012:191-193. 18. Centers for Disease Control and Prevention. Internatiol a doption

Oxford University Press, 2012:515-521.
19. Brauer M, De Villiers J, Mayaphi SH. Evaluation of the Determine ${ }^{\mathrm{TM}}$ fourth generation HIV rapid assay. J Virol Methods 2013;189(1):180-183. [http://dx.doi.org/10.1016/j.jviromet.2013.01.017]

20. South African National Department of Health. The South African Antiretroviral Treatment Guideline 2013: PMTCT Guidelines. Pretoria: Department of Health, 2013. http://web.up.ac.za/sitefiles/ file/45/1335/877/PMTCT\%20guidelines_March\%202013_DoH.pdf (accessed 13 May 2013).

21. Burgard M, Blanch S, Jasseron C, et al. Performance of HIV-1 DNA or HIV-1 RNA tests for early diagnosis of perinatal HIV-1 infection during anti-retroviral prophylaxis. J Pediatr 2012;160(1):60-66. [http://dx.doi.org/10.1016/j.jpeds.2011.06.053

22. Haeri Mazanderani AF, du Plessis NM, Thomas WN, Venter E, Avenant T. Loss of detectability and indeterminate results: Challenges facing HIV infant diagnosis in South Africass expanding ART programme. S Afr Med J 2014;104(8):574-577. [http://dx.doi.org/10.7196/SAMJ.8322]

23. de Almeida Ponde RA. The underlying mechanisms for the 'isolated positivity for the hepatitis surface antigen (HBsAg)' serological profile. Med Microbiol Immunol 2011;200(1):13-22. [http:// dx.doi.org/10.1007/s00430-010-0160-3]

24. Dollard SC, Grosse SD, Ross DS. New estimates of the prevalence of neurological and sensory sequelae and mortality associated with congenital cytomegalovirus infection. Rev Med Virol 2007;17(5):355363. [http://dx.doi.org/10.1002/rmv.544]

25. Bitnum A, Lee E, Ford-Jones, Ryan G. Implications for the fetus of maternal infections in pregnancy In: Cohen J, Opal SM, Powderly WG, eds. Infectious Diseases. 3rd ed. Philadelphia: Elselvie 2010:564-579.

26. Botha JF, Kassianides C, Schneider HR, Song E, Spearman W, van der Merwe SW. South African hepatitis C management guidelines 2010. South African Gastroenterology Review 2010:8(1);20-25.

27. Harrison TJ, Dusheiko GM, Zuckerman AJ. Hepatitis viruses. In: Zuckerman AJ, Banatvala JE Schoub BD, et al., eds. Principles \& Practice of Clinical Virology. 6th ed. Chichester: Wiley-Blackwell, 2009:273-320.

28. Yeung LT, King SM, Roberts EA. Mother-to-infant transmission of hepatitis C virus. Hepatolog 2001;34(2):223-229. [http://dx.doi.org/10.1053//hep.2001.25885]

29. Haeri Mazanderani AF, Ebrahim O. Progressive HIV infection in the presence of a raised $\mathrm{CD} 4^{+}$count: HIV/HTLV-1 co-infection. South African Journal of HIV Medicine 2013;14(2):92-94. [http://dx.doi. org/10.7196/SAJHIVMED.904

30. Verdonck K, Gonzalez E, Van Dooren S, et al. Human T-lymphotropic virus 1: Recent knowledge about an ancient infection. Lancet Infect Dis 2007;7(4):266-281. [http://dx.doi.org/10.1016/S14733099(07)70081-6]

31. American Academy of Pediatrics, Rose SR, American Thyroid Association, Brown RS, Lawson Wilkin Pediatric Endocrine Society. Update of newborn screening and therapy for congenital hypothyroidism. Pediatrics 2006;117(6):2290-2303. [http://dx.doi.org/10.1542/peds.2006-0915]

32. Sutcliffe AG, Soo A, Barnes J. Predictive value of developmental testing in the second year for cognitive development at five years of age. Pediatr Rep 2010;2(2):48-50. [http://dx.doi.org/10.4081/pr.2010.e15] 3. Joint Committee on Infant Hearing. Year 2007 Position Statement: Principles and guidelines for early hearing detection and intervention programs. Pediatrics 2007:120(4):898-921. [http://dx.dol. org/10.1542/peds.2007-2333

34. Health Professions Council of South Africa. Professional Board for Speech, Language and Hearing Profession: Early Hearing Detection and Intervention Programmes in South Africa, Position Statement Year 2007. Pretoria: Health Professions Council of South Africa, 2007. http://www.hpcsa. co.za/downloads/speech_education/early_hearing_detection_statement.pdf (accessed 28 May 2013).

35. American Academy of Audiology. Clinical Practice Guidelines 2011 Childhood Hearing Screening Documents/20110926_ChildhoodHearngScreningGuidelines pdf (accessed 28 May 2013).

Accepted 17 April 2014 


\section{Appendix 1. Medical report: Abandoned children and children prior to} adoption

\begin{tabular}{|c|c|c|c|c|c|c|c|c|c|}
\hline 1 & \multicolumn{9}{|c|}{ IDENTIFYING DETAILS } \\
\hline \multicolumn{10}{|c|}{ FIRST NAME/S } \\
\hline \multicolumn{10}{|c|}{ SURNAME } \\
\hline \multicolumn{10}{|c|}{$\begin{array}{l}\text { DOB/ESTIMATED } \\
\text { AGE }\end{array}$} \\
\hline \multicolumn{10}{|c|}{ GENDER } \\
\hline 2 & \multicolumn{9}{|l|}{ MEDICAL HISTORY } \\
\hline 2.1 & \multicolumn{9}{|l|}{ BIRTH HISTORY } \\
\hline \multicolumn{2}{|c|}{ PLACE OF BIRTH } & & & & \multicolumn{5}{|c|}{ MODE OF DELIVERY } \\
\hline \multicolumn{2}{|c|}{ GESTATIONAL AGE } & & & & \multicolumn{2}{|c|}{ APGAR SCORES } & \multirow[b]{2}{*}{$\mathrm{HC}$} & & \\
\hline \multicolumn{2}{|c|}{ BIRTH PARAMETERS } & WEIC & & $\mathrm{kg}$ & LENGTH & $\mathrm{cm}$ & & & $\mathrm{cm}$ \\
\hline \multicolumn{10}{|c|}{$\begin{array}{l}\text { NEONATAL } \\
\text { COMPLICATIONS }\end{array}$} \\
\hline 2.2 & \multicolumn{9}{|c|}{ MATERNAL HISTORY } \\
\hline \multicolumn{2}{|c|}{$\begin{array}{l}\text { GRAVIDITY } \\
\text { PARITY }\end{array}$} & & & & \multicolumn{2}{|c|}{$\begin{array}{l}\text { PREVIOUS } \\
\text { MISCARRIAGE OR TOP }\end{array}$} & & & \\
\hline \multicolumn{2}{|c|}{$\begin{array}{l}\text { NO. OF CHILDREN ALIVE } \\
\text { WITH AGES }\end{array}$} & & & & \multicolumn{2}{|c|}{$\begin{array}{l}\text { DEATH AND CAUSE OF } \\
\text { DEATH OF SIBLINGS }\end{array}$} & & & \\
\hline \multicolumn{10}{|c|}{$\begin{array}{l}\text { ANTENATAL } \\
\text { COMPLICATIONS }\end{array}$} \\
\hline \multicolumn{2}{|c|}{ HIV RAPID (DATE) } & & & & \multicolumn{2}{|c|}{ HIV RAPID RESULTS } & & & \\
\hline \multicolumn{2}{|c|}{ HIV ELISA (DATE) } & & & & \multicolumn{2}{|c|}{ HIV ELISA RESULTS } & & & \\
\hline \multicolumn{2}{|c|}{ HIV VIRAL LOAD (DATE) } & & & & \multicolumn{2}{|c|}{$\begin{array}{l}\text { HIV VIRAL LOAD } \\
\text { RESULTS }\end{array}$} & & & \\
\hline \multicolumn{2}{|c|}{$\mathrm{CD}^{+}{ }^{+}$CELL COUNT } & & & & \multicolumn{2}{|c|}{ HIV WHO STAGING } & & & \\
\hline \multicolumn{2}{|c|}{ PMTCT INTERVENTIONS } & \multicolumn{2}{|c|}{ MOTHER } & & & BABY & & & \\
\hline \multicolumn{2}{|c|}{ TB DIAGNOSED } & YES & NO & UNKNOWN & TB T & MENT & YES & NO & UNKNOWN \\
\hline RPR & OTHER STIS & & & & & & & & \\
\hline $\begin{array}{l}\text { SMO } \\
\text { DRUC }\end{array}$ & $\begin{array}{l}\text { KING/ALCOHOL/ } \\
\text { HISTORY }\end{array}$ & & & & $\begin{array}{l}\text { FAMILY D } \\
\text { KNOWN }\end{array}$ & SES & & & \\
\hline
\end{tabular}




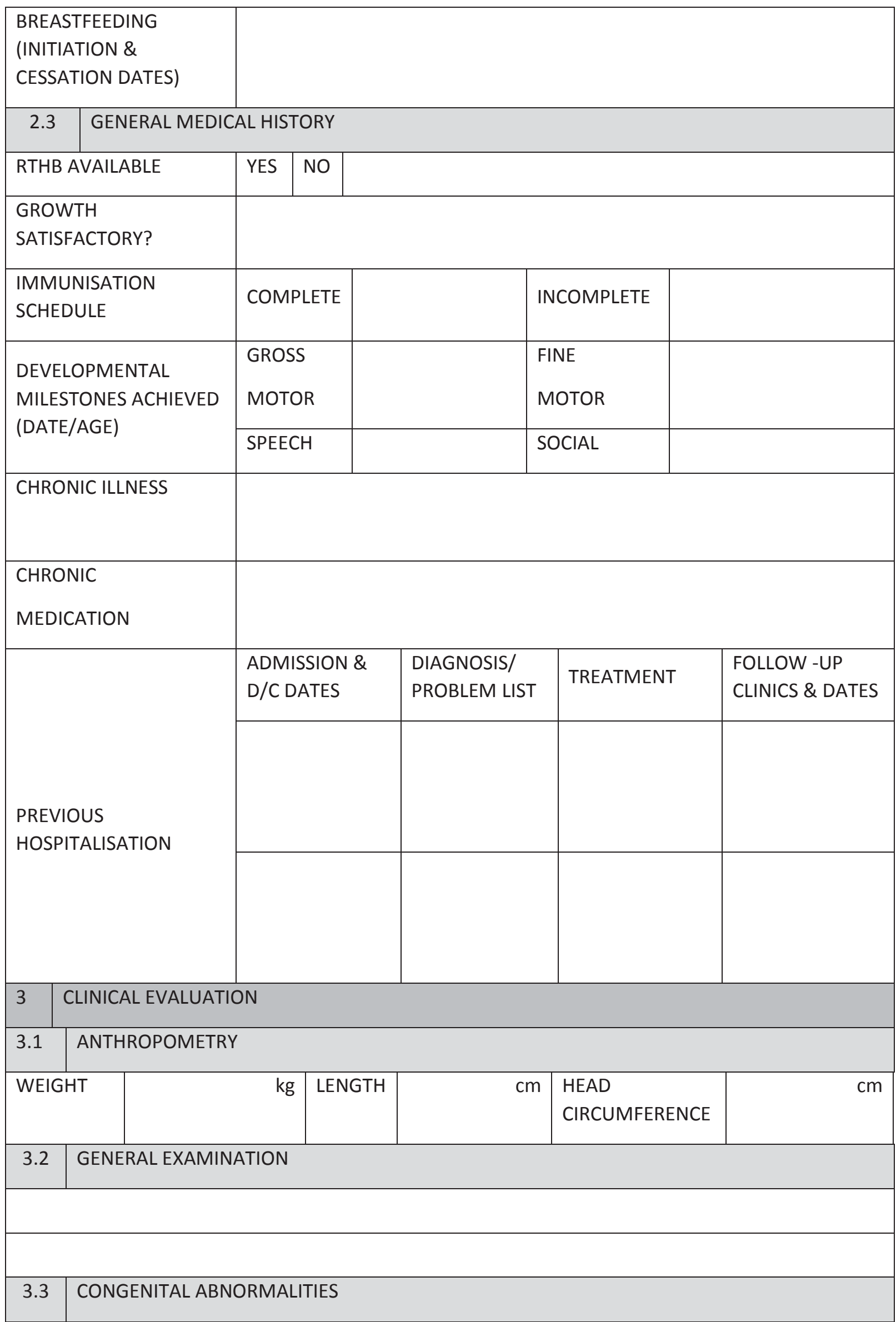




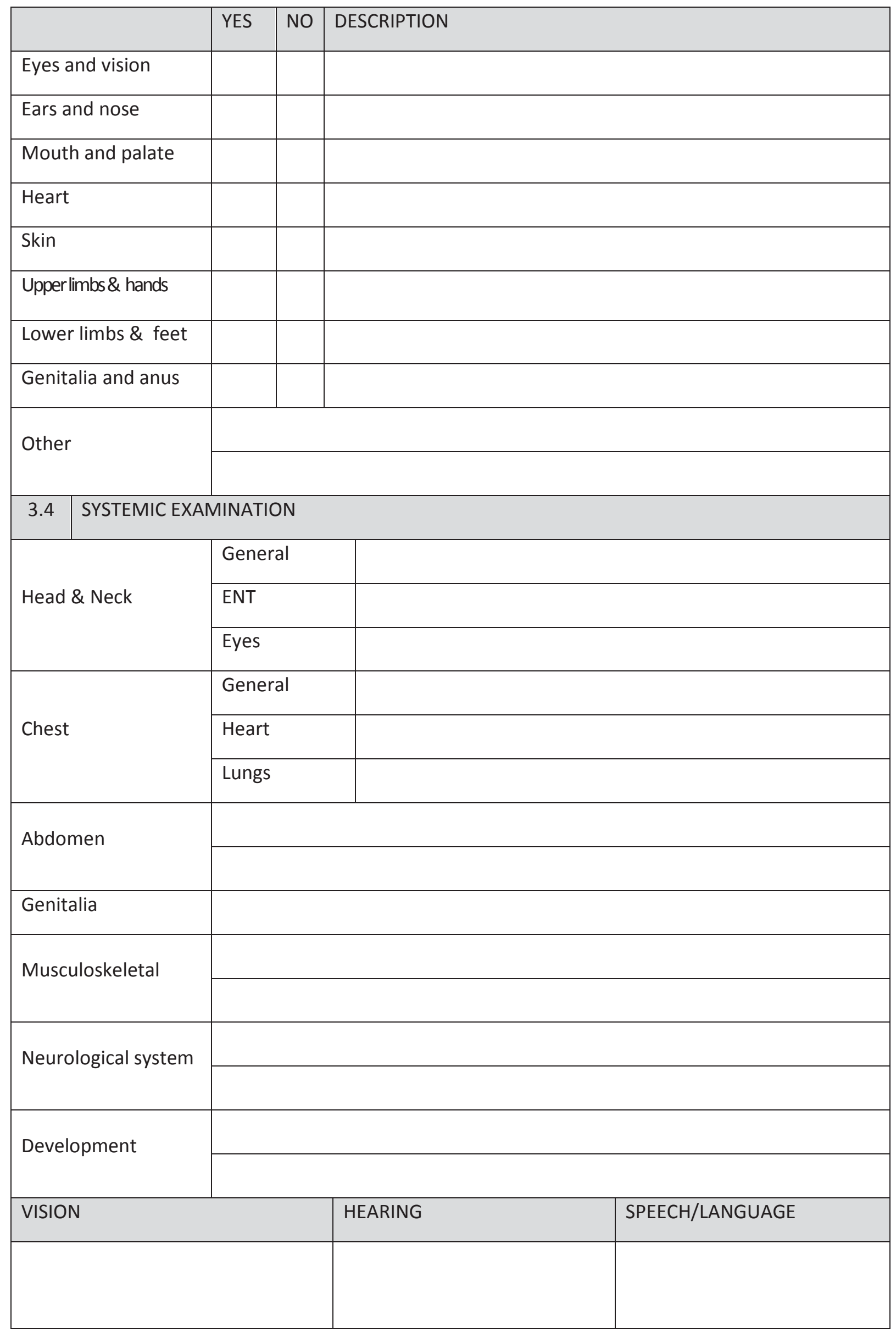




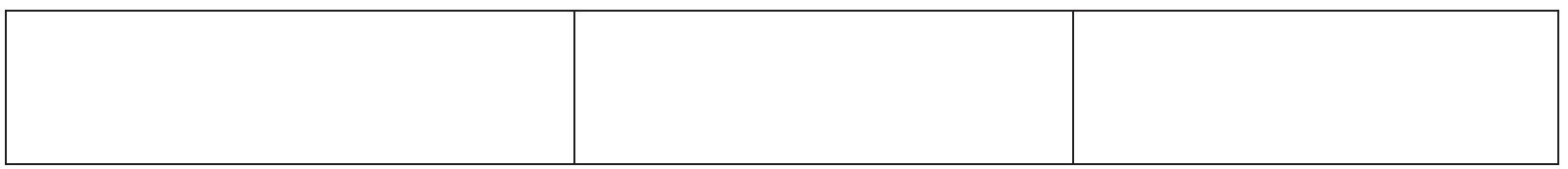

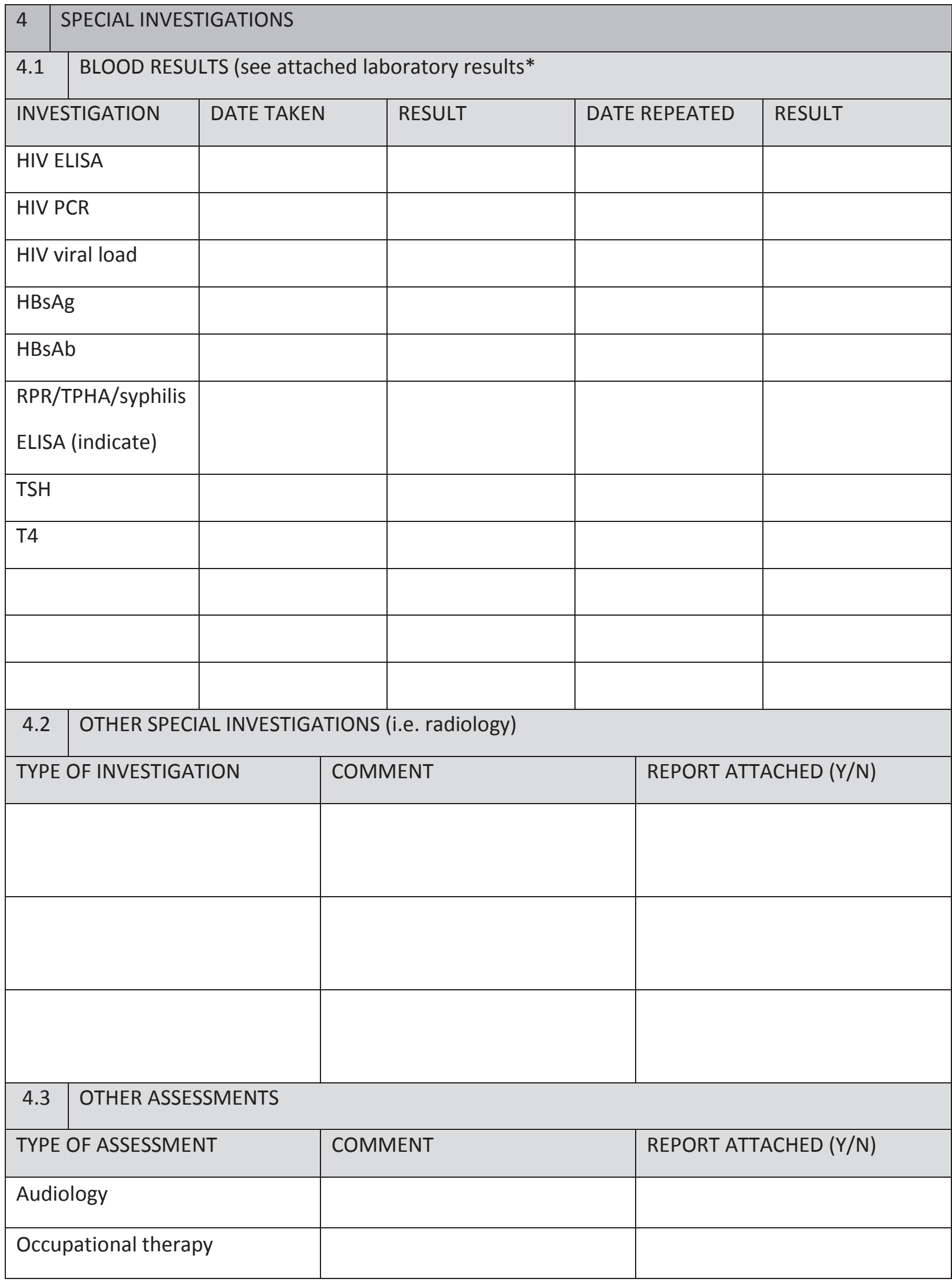




\begin{tabular}{|l|l|l|l|}
\hline \multicolumn{2}{|l|}{ Speech/language therapy } & & \\
\hline \multicolumn{2}{|l|}{ Psychology } & & \\
\hline \multirow{2}{*}{ Other } & \\
\cline { 3 - 4 } & \\
\hline 5 & CONCLUSIONS AND RECOMMENDATIONS \\
\hline
\end{tabular}

*Add additional laboratory investigations and results at end of table. REPORT COMPILED BY:

FULL NAMES:

HPCSA NUMBER: QUALIFICATIONS:

CONTACT ADDRESS:

TEL.: EMAIL:

SIGNATURE:

DATE:

PLEASE ATTACH COPIES OF RTHB/BLOOD RESULTS/ALL SPECIAL INVESTIGATIONS

FOLLOW-UP NOTES/PROGRESS REPORT

\section{FOLLOW-UP REPORT COMPILED BY:}

FULL NAMES:

REGISTRATION NUMBER: QUALIFICATIONS:

CONTACT ADDRESS:

TEL.: EMAIL:

SIGNATURE:

DATE:

\section{FOLLOW-UP NOTES/PROGRESS REPORT}




\begin{tabular}{|l|}
\hline \\
\hline \\
\hline \\
\hline
\end{tabular}

FOLLOW-UP REPORT COMPILED BY:

FULL NAMES:

REGISTRATION NUMBER:

QUALIFICATIONS:

CONTACT ADDRESS:

TEL.:

EMAIL:

SIGNATURE:

DATE:

\begin{tabular}{|l|}
\hline FOLLOW-UP NOTES/PROGRESS REPORT \\
\hline \\
\hline \\
\hline \\
\hline \\
\hline
\end{tabular}

\section{FOLLOW-UP REPORT COMPILED BY:}

FULL NAMES:

REGISTRATION NUMBER:

QUALIFICATIONS:

CONTACT ADDRESS:

TEL.: EMAIL:

SIGNATURE:

DATE:

PLEASE ATTACH COPIES OF RTHB/BLOOD RESULTS/ALL SPECIAL INVESTIGATIONS 